1 Shedding new light on the diet of Norwegian lemmings: DNA

2

3

4 Eeva M. Soininen $^{1^{*}}$, Lucie Zinger ${ }^{2,7}$, Ludovic Gielly ${ }^{2}$, Eva Bellemain ${ }^{3,6}$, Kari Anne Bråthen ${ }^{1}$,

5 Christian Brochmann ${ }^{3}$, Laura S. Epp ${ }^{3}$, Galina Gussarova ${ }^{3}$, Kristian Hassel ${ }^{4}$, John-André

6 Henden $^{1}$, Siw T. Killengreen ${ }^{1}$, Teppo Rämä ${ }^{5}$, Hans K. Sten $\varnothing i e n^{4}$, Nigel G. Yoccoz ${ }^{1}$, Rolf A. Ims ${ }^{1}$

$7{ }^{1}$ Department of Arctic and Marine Biology, University of Troms $\varnothing$, NO-9037 Troms $\varnothing$, Norway

\section{metabarcoding of stomach content}

2Laboratoire d'ECologie Alpine, UMR UJF-UdS-CNRS 5553, Université Joseph Fourier, 2233 rue de la Piscine, BP 53, 38041 Grenoble Cedex 9, France

${ }^{3}$ National Centre for Biosystematics, Natural History Museum, University of Oslo, PO Box 1172 Blindern, NO-0318 Oslo, Norway

${ }^{4}$ Museum of Natural History, Norwegian University of Science and Technology, NO-7491

Trondheim, Norway

${ }^{5}$ Troms $\varnothing$ University Museum, University of Troms $\varnothing$, NO-9037 Troms $\varnothing$, Norway

${ }^{6}$ Current address: Savoie Technolac, Batiment House Boat n7 12, allee du lac de Garde, BP 274, 73375 Le Bourget-du-Lac Cedex, France

${ }^{7}$ Current address: Laboratoire Evolution et Biodiversité Biologique, UMR 5174, Université Paul Sabatier, 118 route de Narbonne, 31062 Toulouse Cedex 9, France

*Corresponding author e-mail:eeva.soininen@uit.no, tel: +47 77620932,

fax: +4777646333 


\section{Abstract}

Lemmings are key herbivores in many arctic food webs and their population dynamics have major impacts on the functioning of tundra systems. However, current knowledge of lemming diet is limited, hampering evaluation of lemming-vegetation interactions. This lack of knowledge is mainly due to methodological challenges, as previously used microhistological methods result in large proportions of poorly resolved plant taxa. We analysed diets of Norwegian lemmings (Lemmus lemmus) in three different habitats using a new method, DNA metabarcoding of stomach contents. To achieve detailed information on ingested vascular plants, bryophytes and fungi, we amplified short fragments of chloroplast DNA (for plants; P6 loop of the trnL intron) and nuclear ribosomal DNA (for fungi; ITS1 region). Our results revealed that lemming diets were dominated by grasses, mainly Avenella flexuosa, and mosses, mainly Dicranum spp., but that a variety of other food items were also eaten. Vascular plant composition of the diets differed between heath, meadow and wetland habitats, whereas bryophyte composition did not. Also a variety of fungal taxa were retrieved, but as most of the identified taxa belong to micromycetes, they were unlikely to be consumed as food. The role of fungi in the diet of lemmings remains to be investigated. We suggest that there may be substantial variation between habitats and regions in lemming diet.

Keywords: Small rodents, Lemmus lemmus, tundra, herbivore, trnL approach, fungi 


\section{Introduction}

45

46

47

48

49

50

51

52

53

54

55

56

57

58

59

60

61

62

63

64

In most tundra ecosystems, lemmings function as the main trophic link between vegetation and predators (Krebs et al. 2003; Ims and Fuglei 2005; Krebs 2011). Hence, their high amplitude population density cycles often have a major impact on tundra food webs (Moen et al. 1993; Gauthier et al. 2004; Henden et al. 2008). To correctly evaluate the effect of lemmings on vegetation - and vice versa - it is crucial to identify what they feed on in the wild, especially since lemming cycles may be driven by plant-herbivore interactions (Turchin et al. 2000; Ekerholm et al. 2001; Oksanen et al. 2008). Knowledge of lemming diet, especially for the Norwegian lemming (Lemmus lemmus), in the wild is, however, scarce (Tast 1991; Batzli 1993; Saetnan et al. 2009; Krebs 2011). Therefore, studies of vegetationlemming interactions often have to make assumptions based on the sparse data available from other areas or habitats (Andersson and Jonasson 1986; Morris et al. 2000; Olofsson et al. 2004) or use generalizations like "broad diet" (Aunapuu et al. 2008) or "moss eaters" (Turchin et al. 2000). Such a lack of knowledge hampers our understanding of lemmingvegetation interactions, and finally our ability to understand the role of lemmings as a trophic link.

Most of the uncertainty about Norwegian lemming diets arises from the small sample size in studies analyzing stomach contents (but see Koshkina (1961) and Tast (1991)) and the coarse categories used to define diet (but see Saetnan et al. (2009)), precluding the generalization of former observations. Low sample size and coarse classification mainly result from 
methodological limitations, as stomach content analysis of rodents using microscopy is timeconsuming, and often has low taxonomic resolution (Soininen et al. 2009). In addition, the potential role of fungi in affecting the diet quality of small rodents has been emphasized (Saikkonen et al. 1998; Huitu et al. 2008), but their abundance and identity in lemming diets are hardly accessible with microhistological methods. As an alternative, DNA metabarcoding, i.e. DNA barcoding of environmental samples coupled with large scale parallel highthroughput sequencing techniques (as defined by Taberlet et al. (2012)), has lately been successfully used to study herbivore diets (Pegard et al. 2009; Kowalczyk et al. 2011; Raye et al. 2011; Pompanon et al. 2012). This approach consists of amplifying and sequencing a standardized DNA region from feces/stomach content, and subsequently identifying and quantifying the organisms composing the diet by comparing the obtained sequences to a reference database (see review by Valentini et al. (2009)). Compared to traditional methods for herbivore diet analysis, DNA metabarcoding provides finer taxonomic resolution, has the potential to identify more taxa, and analyze a large number of samples in addition to being less likely biased by the observer (Soininen et al. 2009; Valentini et al. 2009)

We present here the first species level data on the diet of Norwegian lemmings, using DNA metabarcoding. The species is believed to feed largely on mosses during winter and on a wider variety of forbs, graminoids and shrubs in the summer (Kalela et al. 1961; Koshkina 1961; Stoddart 1967; Hansson 1969; Tast 1991; Batzli 1993; Saetnan et al. 2009). To further assess the variability of Norwegian lemming diets, we used a DNA metabarcoding approach on stomach contents collected during a population peak in different habitats in a low arctic region of Finnmark, north-eastern Norway. To achieve taxonomically detailed information of 
both vascular plants and bryophytes, we used two different primer sets to identify the ingested plants (Taberlet et al. 2007). As the first attempt to evaluate identity of the fungi ingested by Norwegian lemmings, we also analyzed the stomach content using a primer pair developed for DNA metabarcoding of fungi (Epp et al. 2012).

\section{Material and Methods}

\section{Study area and samples}

All samples were collected in the Varanger Peninsula in the north eastern part of Norway $\left(70-71^{\circ} \mathrm{N}, 28-31^{\circ} \mathrm{E}\right)$, in 2007 , using snap-trapping (cf. Henden et al. (2011)). The area is classified as low arctic tundra (Walker et al. 2005). During the summer of 2007 Norwegian lemming populations peaked in the area, followed by a population crash during the winter of 2008 (Henden et al. 2011; Ims et al. 2011). The samples were mainly collected in early September ( $n=39)$, but to achieve a more balanced sample size between habitats one individual trapped in late June was included in the analyses. Samples were collected from two different river catchment areas, namely Komagdalen and Vestre Jakobselv ( $n=20$ for both areas respectively). In both river catchments, three types of habitats were sampled; (1) alpine low-shrub heaths dominated by Empetrum nigrum s. lat., Vaccinium spp. and Betula nana, (2) meadows dominated by grasses and forbs, with interspersed willow shrubs (Salix spp.) and (3) wetlands, dominated by Carex spp. and low shrubs (Salix spp., Betula nana). Most samples were collected from heaths $(n=28)$, whereas sample sizes for meadows and wetlands were lower ( $n=5$ from each habitat, respectively). Two individuals could not be assigned to these habitat categories, and data from these was excluded from the 
comparison between habitats. Difference between the two river catchments was not assessed due to low sample size for meadow and wetland habitats. The mean weight of the sampled Norwegian lemmings was $50 \mathrm{~g}( \pm 16 \mathrm{SD}, \mathrm{n}=22)$ for females and $50 \mathrm{~g}( \pm 11 \mathrm{SD}, \mathrm{n}=17$, weight lacking for one individual) for males. The sampled Norwegian lemmings contained both adults and juveniles, although age was not determined for all individuals. For females, $n=6$ adults, 3 juveniles and 14 unknown, for males $n=5$ adults, 3 juveniles and 8 unknown. Part of the Norwegian lemmings $(n=16)$ were dissected in the field and their stomachs stored in $70 \%$ ethanol. The remaining individuals $(n=24)$ were frozen and dissected later at the laboratory. All stomachs were opened in the laboratory and contents were homogenized and dried.

\section{Diet analysis}

Stomach contents were analyzed using DNA metabarcoding. Identity and abundance of plants in stomachs was assessed using two universal primer pairs for plants, which both use the P6-loop of the chloroplast trnL (UAA) intron; $g$ - $h$ and $c-h$ (Taberlet et al. 1991; Taberlet et al. 2007). The $g$ - $h$ primer pair gives taxonomically relatively precise results for small rodent diets (Soininen et al. 2009). Its provides, however, results biased towards seed plants. To achieve a complementary picture of all plant taxa in Norwegian lemming diets we also used primer pair $c-h$, which is universal for all plant taxa (bryophytes included). We analyzed presence of fungi using primer pair ITS-Fungi, which is developed for DNA metabarcoding approaches and combines primers ITS5 and 5.8S_fungi (White et al. 1990; Epp et al. 2012).

One sample per individual was analyzed following the methods for DNA extraction, amplification, quantification and tagging described in detail by Soininen et al. (2009). 
Sequencing was done by the Génoscope (French National Sequencing Center, EVRY), on a 454 GS FLX sequencer (Roche Diagnostics) using Titanium chemistry. Details on retrieving taxonomic units based on raw sequence data are given, for each primer pair separately, in Supplementary Table S1.

As taxonomic reference libraries for the primer pair $g$ - $h$, we first used a combined library of 815 arctic species (Sønstebø et al. 2010) and additional 849 boreal vascular plant taxa at the rank of species, subspecies or variety (Brochmann et al. unpublished). We included in the final dataset all sequences with $a \geq 98 \%$ match with this reference library. Of the remaining sequences, we included those with $a \geq 98 \%$ match to a sequence in a database constructed by extracting P6-loop sequences from the EMBL Nucleotide Sequence Database by using the software ecoPCR (available at http://www.grenoble.prabi.fr/trac/ecoPCR). For the $c-h$ primer pair, we used the same taxonomic reference library of arctic and boreal vascular plant species, supplemented with 455 arctic and boreal bryophyte species (Gussarova et al. unpublished). For the ITS-Fungi primer pair, we created a reference database by extracting sequences of the targeted region from the EMBL Nucleotide Sequence Database with ecoPCR. From the two unpublished reference libraries, the sequences by which the taxa were identified in this study ( $n=83$ for vascular plants and $n=48$ for bryophytes) were submitted to the EMBL Database (accession numbers embl:HE993553-ebml:HE993683). For both $g$ - $h$ and $c-h$ primers the retrieved groups were afterwards compared both with the known regional flora and the reference libraries coverage of all relevant taxa. Details of these taxonomic adjustments are described in Appendix 1. Nomenclature for vascular plants 
follows the Annotated Checklist of the Panarctic Flora (PAF) (available at:

http://nhm2.uio.no/paf/, accessed 15.6.2012).

The resulting datasets consisted of a count of sequences per taxon per individual Norwegian lemming. For primer pairs $g-h$ and $c-h$, we calculated the proportion of different taxa per individual. Even though DNA metabarcoding data for plants probably reflects small rodent diets well (Soininen et al. 2009), some biases may occur (Soininen et al. 2009; Pompanon et al. 2012) and we therefore also report the number of individuals in which a given taxon was found. Because we are not aware of how well the DNA metabarcoding results for fungi reflect relative abundances of taxa, we calculated only the number of individuals in which different fungal taxa were found. We used the $c-h$ dataset to compare the proportions of seed plants, ferns and fern allies (i.e. vascular non-seed plants) and bryophytes (i.e. mosses and liverworts) in diets and to assess the proportions of different bryophyte taxa. We used data from primer pair $g$ - $h$ to study the proportions of seed plant taxa. We compared diets between habitats, but did no statistical analysis due to low sample size from wetlands and meadows.

\section{Results}

Mean proportions of bryophytes, ferns and fern allies and seed plants in Norwegian lemming diets were 0.32 (SE 0.05), 0.02 (SE 0.01) and 0.63 (SE 0.05), respectively. Five individuals, i.e. $13 \%$ of the animals included in this study, had not ingested any bryophytes. Two of these individuals came from the heath, two from the meadow and one from the wetland habitat. 
178 Among seed plants, grasses (Poaceae, mean proportion 0.49 (SE 0.06)) emerged as the most 179 important group (Table 1, Figure 1). Among grasses, Avenella flexuosa was the dominant 180 species, representing 0.67 of grasses and 0.33 of all seed plants in diets. Other relatively 181 abundant groups were sedges (Cyperaceae, mean proportion 0.15 (SE 0.05)), willows 182 (Salicaceae mean proportion 0.09 (SE 0.04)) and forbs of the family Polygonaceae (mean proportion 0.08 (SE 0.04)), especially Rumex spp. In addition, a range of different plant taxa was found in small quantities (Table 1 and Supplementary Table S2).

The bryophytes retrieved were dominated by mosses, liverworts being rare (one liverwort species occurred in one individual). The dominant moss family was Dicranaceae and the most frequentspecies was Dicranum scoparium, which alone made up 0.20 of mosses in the diets (Figure 2). In addition, sequences belonging to the Dicranaceae at different taxonomic levels (species, genus and family), were frequent. Several non-Dicranaceae mosses were also present, but their abundance was low (Figure 2, Supplementary Table S2).

Diets of individuals from the different habitats seemed to differ in terms of seed plant composition, although all of these differences have to be interpreted with caution due to small sample sizes (Figure 1). The clearest difference between habitats was the dominance of grasses in the heaths compared with a more varied diet in both wetlands and meadows. No similar difference was found for mosses; the Dicranaceae dominated in all habitats 
(Figure 2). The proportions of mosses in diets were 0.44 (SE 0.06), 0.20 (SE 0.7) and 0.19 (SE

$0.10)$ in heath, meadow and wetland habitats, respectively.

Most fungi that were successfully identified tothe species level belonged to micromycetes one of the identified fungi (Caloplaca flavocitrina), present in one individual, is known as lichen-forming. Three individuals contained no sequences of fungi.

\section{Discussion}

We found that Norwegian lemming diet was dominated by grasses, of which Avenella

flexuosa composed more than half, and mosses, mainly of the genus Dicranum. In addition

to grasses, Norwegian lemmings had ingested a diverse range of other seed plants, whereas

habitats in terms of moss proportion and seed plant composition. A variety of fungi were that are likely to serve as food.

Notably, our results show a taxonomical precision and diversity of food items which is clearly higher than observed in previous studies on the diet of the Norwegian lemming (Stoddart 1967; Hansson 1969; Tast 1991; Saetnan et al. 2009). However, inference of the quantity of each ingested taxon from the number of DNA sequences retrieved should be done with 
some caution. The DNA metabarcoding method has been directly compared with the traditional microhistological approach for voles, indicating that the two methods identify similar proportions of food items (Soininen et al. 2009). However, factors biasing the food item proportions may occur in each of the different steps from ingestion by the animal to identification and counting of sequence reads obtained. These factors include differential digestibility of the ingested food species, differences in the barcode copy number per species and bias introduced in the PCR and in the emulsion PCR prior to sequencing, where shorter reads may preferentially be amplified (Engelbrektson et al. 2010) (for a thorough description of DNA metabarcoding methodology for diet analysis and potential errors related to it, see Pompanon et al. (2012)). A conclusive test of how well the ingested food item proportions correspond to the proportions that are detected by the DNA metabarcoding method would necessitate an analysis of a diet of known proportions, but this is outside the scope of the current study.

The general pattern that Norwegian lemmings feed mainly on grasses and mosses during summer has also been found in most other studies (Stoddart 1967; Hansson 1969; Tast 1991). Nevertheless, our results suggest that lemming diet is both more diverse and includes more vascular plant species than previously believed. For example, Tast (1991) states that "Norwegian lemmings feed mostly on mosses in all habitats and seasons when they are available", which is clearly contradictory to our results. Our results suggest that the dominance of grasses and mosses is most pronounced in the heath habitat, and that the diet is more diverse in the meadow and wetland habitats. Such differences in lemming diets between habitats are likely to be attributed to the availability and quality of different food 
items (Batzli 1993). However, a larger sample size would be required for investigating whether the observed patterns are consistent, and detailed data on vegetation would be needed for understanding their causes.

Comparison of our results with previous studies suggests that there is regional variation in the feeding habits of the Norwegian lemming. For example, Saetnan et al. (2009) report Norwegian lemming diets dominated by Cyperaceae in "alpine willow thicket-meadow" habitat in central Norway, which resemble the meadow habitats in the current study. We found a quite large proportion of sedges in the diets of Norwegian lemmings caught in meadows as well as in the two other habitats, but grasses and mosses to be generally more important. Further, we found that Avenella flexuosa alone formed one third of the seed plants in the Norwegian lemming diets. Previous studies have found variable amount of this grass in Norwegian lemming diets, from being a frequently eaten grass (Hansson 1969) to not being present at all (Saetnan et al. 2009). Avenella flexuosa is a common grass in the study area of the latter study, as in our study area (Saetnan et al. 2009; Ravolainen et al. 2013). Thus, difference in availability alone is unlikely to explain the recorded difference in the use of this species. While some of this discrepancy may be explained by low resolution of the microhistological methods, it seems unlikely that this would be the case for such distinct groups as sedges, grasses and mosses. We therefore suggest that in addition to differences in diet between habitats, as suggested by our results, there may be regional differences in Norwegian lemming diet. Such variation may cause lemming-vegetation interactions to differ between habitats and regions and thus cause such an attribute as population outbreak amplitude to exhibit spatial variation (Ims et al. 2011). 
The majority of mosses we found in Norwegian lemming diets belonged to the genus

Dicranum, which is in line with previous findings from both Norwegian lemmings (Kalela et

al. 1961; Stoddart 1967; Tast 1991) and wood lemmings (Myopus schisticolor) (Eskelinen

2002). Interestingly, Eskelinen (2002) suggested that the high nitrogen content he observed

in Dicranum could explain such a preference in wood lemmings. On the other hand, Hansson

(1969) suggested Hylocomium splendens to be the most commonly eaten moss by

Norwegian lemmings in northern Sweden. Dicranum spp. are generally more frequent in

arctic and alpine vegetation than H. splendens (Austrheim et al. 2005; Hassel et al. 2012), and high availability may explain the dominance of Dicranum spp. in the Norwegian lemming diet. We suggest that either methodology or different abundance or quality of available mosses in vegetation could have caused this discrepancy. This interpretation of betweenhabitat and -site variability is supported by the findings by Kalela et al. (1961), whose feeding experiments indicate that Norwegian lemmings do not exclusively prefer Dicranum spp..

Most macromycetes (i.e. fungi which produce large fruit bodies) in the study area that could serve as food for Norwegian lemmings belong to Agaricomycetes (Hansen and Knudsen 1992), which occurred sparsely in our samples. Instead, the majority of the identified species probably eaten passively, with plants (Jensen et al. 2011), or they may be part of the flora in the digestive system of Norwegian lemmings. Whether Agaricomycetes were actually present but undetected, were identified at higher taxonomic levels (most individuals had unidentified fungi in their diet) or were absent because the Norwegian lemmings do not feed 
on fungi cannot be firmly concluded. As the presence of fungi and plants was analyzed separately, their abundances cannot be compared. Most of the analyzed individuals were collected during autumn, when large fruit bodies of Agaricomycetes are in general most abundant. Even though the macromycetes are more available in the autumn they were not found in Norwegian lemming diets from the same period. We therefore find it unlikely that they would constitute an important part of Norwegian lemming diet during other seasons. Hence, our results support the conclusion of Koshkina (1961), that fungi are unimportant as food for Norwegian lemmings.

Rather than serving as food, ingested micromycetes are more likely to have implications for food quality of Norwegian lemmings. Many endophytic fungi produce toxins that are harmful for mammals, although certain fungal associates of plants may have also positive effects for small rodents (Saikkonen et al. 1998; Saari et al. 2010). A diverse fungal community is associated with both mosses and grasses, even if the ecology of such interactions is poorly known (Davey and Currah 2006; Kauserud et al. 2008; Jensen et al. 2011). It is thus possible that at least some of the fungi which we found may change the quality of plants as food for Norwegian lemmings. More knowledge of the fungi in Norwegian lemming diets as well as in their food plants is clearly needed to understand their ecological role for Norwegian lemmings. The variable diets of Norwegian lemmings between habitats and regions, suggested by our results, in combination with the variable use of habitats throughout the phases of population cycles (Kalela et al. 1961; Tast 1991), may have implications for the quality of ingested food and thus for the condition of the individual Norwegian lemmings. 


\section{Acknowledgements}

312 We thank Arne-Petter Sarre, Alfred Ørjebo and all field assistants for collecting lemming

313 samples in 2007; Torbjørn Alm, Knut Rydgren and Leif Einar Støveren for taxonomic

314 expertise; Christian Miquel, Delphine Rioux, Alice Valentini, Virginia Mirré and Audun

315 Schrøder-Nielsen for technical assistance in the laboratory; Eric Coissac and Frédéric Boyer

316 for help in data handling; Pierre Taberlet for fruitful discussions and two anonymous

317 reviewers for valuable comments that have improved the manuscript. This project was

318 funded by the Research Council of Norway (Ecosystem Finnmark) and Oskar Huttunen Fond

319 (PhD scholarship for EMS). Funding for building the taxonomic reference libraries was

320 obtained from the Research Council of Norway (the BarFrost project, grant no 191627/V40

321 to $\mathrm{CB})$.

\section{Conflict of Interest}

324 We would like to mention that L.G. is one of the co-inventors of a patent concerning $g-h$

325 primers and the subsequent use of the P6 loop of the chloroplast trnL (UAA) intron for plant

326 identification using degraded template DNA. These patents only restrict commercial

327 applications and have no impact on the use of this locus by academic researchers. 
Andersson M, Jonasson S (1986) Rodent cycles in relation to food resources on an alpine heath. Oikos 46:93-106

Aunapuu M, Dahlgren J, Oksanen T, Grellmann D, Oksanen L, Olofsson J, Rammul U, Schneider M, Johansen B, Hygen HO (2008) Spatial patterns and dynamic responses of arctic food webs corroborate the exploitation ecosystems hypothesis (EEH). Am Nat 171:249-262

Austrheim G, Hassel K, Mysterud A (2005) The role of life history traits for bryophyte community patterns in two contrasting alpine regions. Bryologist 108:259-271

Batzli GO (1993) Food selection by lemmings. In: Stensetch NC, Ims RA (eds) The Biology of Lemmings. 1 edn. Academic Press, London, pp 281-301

Davey ML, Currah RS (2006) Interactions between mosses (Bryophyta) and fungi. Can J Bot 84:15091519

Ekerholm P, Oksanen L, Oksanen T (2001) Long-term dynamics of voles and lemmings at the timberline and above the willow limit as a test of hypotheses on trophic interactions. Ecography 24:555-568. doi:10.1034/j.1600-0587.2001.d01-211.x

Engelbrektson A, Kunin V, Wrighton KC, Zvenigorodsky N, Chen F, Ochman H, Hugenholtz P (2010) Experimental factors affecting PCR-based estimates of microbial species richness and evenness. Isme J 4 (5):642-647. doi:10.1038/ismej.2009.153

Epp L, Boessenkool S, Bellemain E, Haile J, Esposito A, Riaz T, Erseus C, Gusarov VI, Edwards ME, Johnsen A, Steinøien HK, Hassel K, Kauserud H, Yoccoz NG, Bråthen KA, Willerslev E, Taberlet P, Coissac E, Brochmann C (2012) New environmental metabarcodes for analysing soil DNA: potential for studying past and present ecosystems. Mol Ecol 21:1821-1833

Eskelinen O (2002) Diet of the wood lemming Myopus schisticolor. Ann Zool Fenn 39:49-57

Gauthier G, Bêty J, Giroux JF, Rochefort L (2004) Trophic interactions in a High Arctic snow goose colony. Integr Comp Biol 44 (2):119-129

Hansen L, Knudsen H (eds) (1992) Nordic macromycetes vol. 2. Polyporales, Boletales, Agaricales, Russulales. Nordsvamp, Copenhagen

Hansson L (1969) Spring populations of small mammals in central Swedish Lapland in 1964-68. Oikos 20:431-450

Hassel K, Prest $\varnothing$ T, N.M. S (2012) Bryophyte diversity in high and low arctic Greenland. Establishment of permanent monitoring transects and bryophyte and bryophyte mapping in Zackenberg and Kobbefjord 2009-2010. Scientific Report from DCE - Danish Centre for Environment and Energy No. 2/. Aarhus University, Roskilde, Denmark

Henden J-A, Bardsen BJ, Yoccoz NG, Ims RA (2008) Impacts of differential prey dynamics on the potential recovery of endangered arctic fox populations. J Appl Ecol 45:1086-1093. doi:10.1111/j.1365-2664.2008.01515.x

Henden J-A, Ims RA, Yoccoz NG, Sørensen R, Killengreen ST (2011) Population dynamics of tundra voles in relation to configuration of willow thickets in southern arctic tundra. Pol Biol 34:533540. doi:10.1007/s00300-010-0908-7

Hill MO, Bell N, Bruggeman-Nannenga MA, Brugues M, Cano MJ, Enroth J, Flatberg KI, Frahm JP, Gallego MT, Garilleti R, Guerra J, Hedenas L, Holyoak DT, Hyvonen J, Ignatov MS, Lara F, Mazimpaka V, Munoz J, Söderström L (2006) An annotated checklist of the mosses of Europe and Macaronesia. J Bryol 28:198-267

Huitu O, Helander M, Lehtonen P, Saikkonen K (2008) Consumption of grass endophytes alters the ultraviolet spectrum of vole urine. Oecologia 156:333-340

Ims RA, Fuglei E (2005) Trophic interaction cycles in tundra ecosystems and the impact of climate change. BioScience 55:311-322

Ims RA, Yoccoz NG, Killengreen ST (2011) Determinants of lemming outbreaks. PNAS 108:1970-1974. doi:10.1073/pnas.1012714108 
Jensen JB, González VT, Guevara DU, Bhuvaneswari TV, Wäli PR, Tejesvi MV, Pirttilä AM, Bazely D, Vicari M, Bråthen KA (2011) Kit for detection of fungal endophytes of grasses yields inconsistent results. Methods Ecol Evol 2:197-201. doi:10.1111/j.2041-210X.2010.00066.x Kalela O, Koponen T, Lind EA, Skarén U, Tast J (1961) Seasonal change of habitat in the Norwegian lemming Lemmus lemmus (L.). Ann Acad Sci Fenn A IV 55:1-72

Kauserud H, Mathiesen C, Ohlson M (2008) High diversity of fungi associated with living parts of boreal forest bryophytes. Botany 86:1326-1333

Koshkina TV (1961) New data on the nutrition of the Norwegian lemming (Lemmus lemmus). Bull Mosk Obshch Ispytal Prirod 66:15-31 (in Russian)

Kowalczyk R, Taberlet P, Coissac E, Valentini A, Miquel C, Kaminski T, Wójcik JM (2011) Influence of management practices on large herbivore diet-Case of European bison in Bialowieza primeval forest (Poland). For Ecol Manag 261:821-828

Krebs C (2011) Of lemmings and snowshoe hares: The ecology of northern Canada. PRSB 278:481489

Krebs CJ, Danell K, Angerbjörn A, Agrell J, Berteaux D, Bråthen KA, Danell O, Erlinge S, Fedorov V, Fredga $K$, Hjältén J, Högstedt G, Jónsdóttir IS, Kenney AJ, Kjellén N, Nordin T, Roininen $H$, Svensson M, Tannerfeldt M, Wiklund C (2003) Terrestrial trophic dynamics in the Canadian Arctic. Can J Zool 81:827-843

Moen J, Lundberg PA, Oksanen L (1993) Lemming grazing on snowbed vegetation during a population peak, northern Norway. Arct Alp Res 25:130-135. doi:10.2307/1551549

Morris DW, Davidson DL, Krebs CJ (2000) Measuring the ghost of competition: Insights from densitydependent habitat selection on the co-existence and dynamics of lemmings. Evol Ecol Res 2:41-67

Oksanen T, Oksanen L, Dahlgren J, Olofsson J (2008) Arctic lemmings, Lemmus spp. and Dicrostonyx spp.: Integrating ecological and evolutionary perspectives. Evol Ecol Res 10:415-434

Olofsson J, Hulme PE, Oksanen L, Suominen O (2004) Importance of large and small mammalian herbivores for the plant community structure in the forest tundra ecotone. Oikos 106:324334. doi:10.1111/j.0030-1299.2004.13224.x

Pegard A, Miquel C, Valentini A, Coissac E, Bouvier F, Francois D, Taberlet P, Engel E, Pompanon F (2009) Universal DNA-based methods for assessing the diet of grazing livestock and wildlife from feces. J Agric Food Chem 57:5700-5706

Pompanon F, Deagle BE, Symondson WOC, Brown DS, Jarman SN, Taberlet P (2012) Who is eating what: Diet assessment using next generation sequencing. Mol Ecol 21:1931-1950

Ravolainen VT, Bråthen KA, Ims RA, Yoccoz NG, Soininen EM (2013) Shrub patch configuration at the landscape scale is related to diversity of adjacent herbaceous vegetation. Plant Ecol Div in press. doi:10.1080/17550874.2013.773104

Raye G, Miquel C, Coissac E, Redjadj C, Loison A, Taberlet P (2011) New insights on diet variability revealed by DNA barcoding and high-throughput pyrosequencing: Chamois diet in autumn as a case study. Ecol Res 26:265-276

Saari S, Sundell J, Huitu O, Helander M, Ketoja E, Ylönen H, Saikkonen K (2010) Fungal-mediated multitrophic interactions - Do grass endophytes in diet protect voles from predators? PLoS ONE 5 (3):e9845. doi:10.1371/journal.pone.0009845

Saetnan ER, Gjershaug JO, Batzli GO (2009) Habitat use and diet composition of Norwegian Lemmings and Field Voles in central Norway. J Mammal 90:183-188. doi:10.1644/07-mamm-a-259.1

Saikkonen K, Faeth SH, Helander M, Sullivan TJ (1998) Fungal endophytes: A continuum of interactions with host plants. Annu Rev Ecol Evol Syst 29:319-343

Soininen EM, Valentini A, Coissac E, Miquel C, Gielly L, Brochmann C, Brysting AKS, J. H., Ims RI, Yoccoz NG, Taberlet P (2009) Analysing diet of small herbivores: The efficiency of DNA barcoding coupled with high-throughput pyrosequencing for deciphering the composition of complex plant mixtures. Front Zool 6:16. doi:10.1186/1742-9994-6-16

Stoddart DM (1967) A note on the food of the Norway lemming. J Zool 151:211-213 
Sønstebø JH, Gielly L, Brysting A, Elven R, Edwards M, Haile J, Willerslev E, Coissac E, Roiux DaS, J., Taberlet $P$, Brochmann $C$ (2010) Using next-generation sequencing for molecular reconstruction of past Arctic vegetation and climate. Mol Ecol Resour 10:1009-1018 Taberlet P, Coissac E, Hajibabaei M, Rieseberg LH (2012) Environmental DNA. Mol Ecol 21:1789-1793 Taberlet $\mathrm{P}$, Coissac E, Pompanon F, Gielly L, Miquel C, Valentini A, Vermat T, Corthier G, Brochmann C, Willerslev E (2007) Power and limitations of the chloroplast trnL (UAA) intron for plant DNA barcoding. Nucleic Acid Res 35:e14. doi:10.1093/nar/gkl938

Taberlet P, Gielly L, Patou G, Bouvet J (1991) Universal primers for amplification of 3 noncoding regions of chloroplast DNA. Plant Mol Biol 17:1105-1109

Tast J (1991) Will the Norwegian Lemming become endangered if climate becomes warmer. Arct Alp Res 23:53-60

Turchin P, Oksanen L, Ekerholm P, Oksanen T, Henttonen H (2000) Are lemmings prey or predators? Nature 405:562-565

Valentini A, Pompanon F, Taberlet P (2009) DNA barcoding for ecologist. Trends Ecol Evol 24:110-117

Walker DA, Raynolds MK, Daniels FJA, Einarsson E, Elvebakk A, Gould WA, Katenin AE, Kholod SS, Markon CJ, Melnikov ES, Moskalenko NG, Talbot SS, Yurtsev BA, Team C (2005) The circumpolar Arctic vegetation map. J Veg Sci 16:267-282. doi:10.1111/j.16541103.2005.tb02365.x

White T, Bruns T, Lee S, Taylor J (1990) Amplification and direct sequencing of fungal ribosomal RNA genes for phylogenetics. In: Innins MA, Gelfand DH, Sninski JJ, White TJ (eds) PCR-Protocols A Guide to Methods and Applications. Academic Press, San Diego, pp 315-322 
Table 1 Composition of seed plants (mean proportion of DNA sequences of spermatophytes taxa for which the identity was adjusted; "+" indicates that at least part of the sequences

461 included in the taxon were re-assigned to a more specific taxonomic level,"-“" the opposite; " $F$ " indicates that this change was done based on the known regional flora and " $\mathrm{B}$ " that it was done due to lack of relevant reference species in the databases used. Included are taxa with a mean $\%>0.1$.

\begin{tabular}{|c|c|c|c|c|c|}
\hline Family & Genus & Species & Mean \% (SE) & Frequency & Change \\
\hline \multirow[t]{5}{*}{ Poaceae } & & & $48.8(6)$ & 40 & $-F$ \\
\hline & Avenella & Avenella flexuosa & $33.6(5.1)$ & 37 & \\
\hline & Festuca & & $3.2(1.4)$ & 31 & \\
\hline & Poa & & $0.9(0.2)$ & 30 & \\
\hline & Anthoxanthum & Anthoxanthum nipponicum & $0.1(0)$ & 9 & \\
\hline \multirow[t]{3}{*}{ Cyperaceae } & & & $15(4.5)$ & 26 & \\
\hline & Carex & & $10.1(3.3)$ & 23 & $-B$ \\
\hline & Eriophorum & & $5(2.4)$ & 14 & \\
\hline \multirow[t]{2}{*}{ Salicaceae } & & & $9.2(4.1)$ & 29 & \\
\hline & Populus & Populus tremula & $2.4(2.4)$ & 3 & $+\mathrm{F}$ \\
\hline \multirow[t]{3}{*}{ Polygonaceae } & & & $7.9(3.7)$ & 30 & \\
\hline & Rumex & & $7.2(3.7)$ & 27 & $-F$ \\
\hline & Bistorta & Bistorta vivipara & $0.7(0.3)$ & 26 & \\
\hline \multirow[t]{6}{*}{ Ericaceae } & & & $6.1(2.6)$ & 33 & \\
\hline & Vaccinium & & $2.5(1.2)$ & 27 & \\
\hline & Vaccinium & Vaccinium myrtillus & $1.9(1)$ & 25 & \\
\hline & Vaccinium & Vaccinium uliginosum & $0.1(0.1)$ & 13 & \\
\hline & Empetrum & Empetrum nigrum s.lat. & $2(0.9)$ & 18 & $+\mathrm{F}$ \\
\hline & Kalmia & Kalmia procumbens & $1.5(1.5)$ & 2 & \\
\hline Betulaceae & Betula & & $6.6(2.4)$ & 28 & \\
\hline Cornaceae & Chamaepericylum & Chamaepericylum suecicum & $1(0.7)$ & 16 & \\
\hline \multirow[t]{3}{*}{ Caryophyllaceae } & & & $0.9(0.9)$ & 3 & \\
\hline & Cerastium & & $0.9(0.9)$ & 2 & \\
\hline & & Cerastium fontanum coll. & $0.9(0.9)$ & 1 & \\
\hline Asteraceae & & & $0.7(0.3)$ & 22 & $-F$ \\
\hline \multirow[t]{2}{*}{ Ranunculaceae } & & & $1.1(0.6)$ & 21 & \\
\hline & Ranunculus & & $1(0.6)$ & 20 & $-F$ \\
\hline
\end{tabular}




\begin{tabular}{llllll}
\hline Juncaceae & & & $1.3(1.1)$ & 11 \\
& Juncus & & $1.3(1.1)$ & 10 & \\
& Juncus & Juncus trifidus & $0.7(0.6)$ & 3 & \\
\hline Orchidaceae & Listera & Listera cordata & $0.3(0.3)$ & 1 & $-\mathrm{F}$ \\
\hline Rosaceae & & & $0.2(0.2)$ & 8 & \\
& \multirow{2}{*}{ Filipendula } & Filipendula ulmaria & $0.2(0.2)$ & 4 & \\
\hline Orobanchaceae & & & $0.1(0)$ & 6 & \\
\hline Violaceae & Viola & \multirow{2}{*}{$0.1(0)$} & 7 \\
& & Viola biflora & $0.1(0)$ & 6 \\
\hline Classified above family level & & $1.3(0.7)$ & & \\
\hline \hline
\end{tabular}

465 
466 Fig. 1 Proportion (mean and SE) of seed plant sequences per lemming stomach in three

467 different habitats, (using $g$ - $h$ primer pair). Category "other ericoids" includes sequences

468 assigned to taxa that contain both deciduous and evergreen ericoid shrubs; category "other

469 graminoids" includes sequences assigned to a taxonomic level which contains both grasses

470 and sedges; category "alternative N" includes hemiparasites and nitrogen fixers.

472 Fig. 2 Proportion (mean and SE) of moss sequences in lemming diets (using $c-h$ primer pair)

473 in three different habitats. At each taxonomic level, the contributions from lower levels are

474 presented when known (e.g. Dicranum includes both $D$. flexicaule and $D$. scoparum, as well

475 as sequences assigned to Dicranum as a genus). Taxa with only one representative in

476 Fennoscandia are plotted at upper taxonomic level (genus Aulacomnium within family

477 Aulacomniaceae and Pleurozium schreberi within genus Pleurozium) (Hill et al. 2006). 
Fig. 1

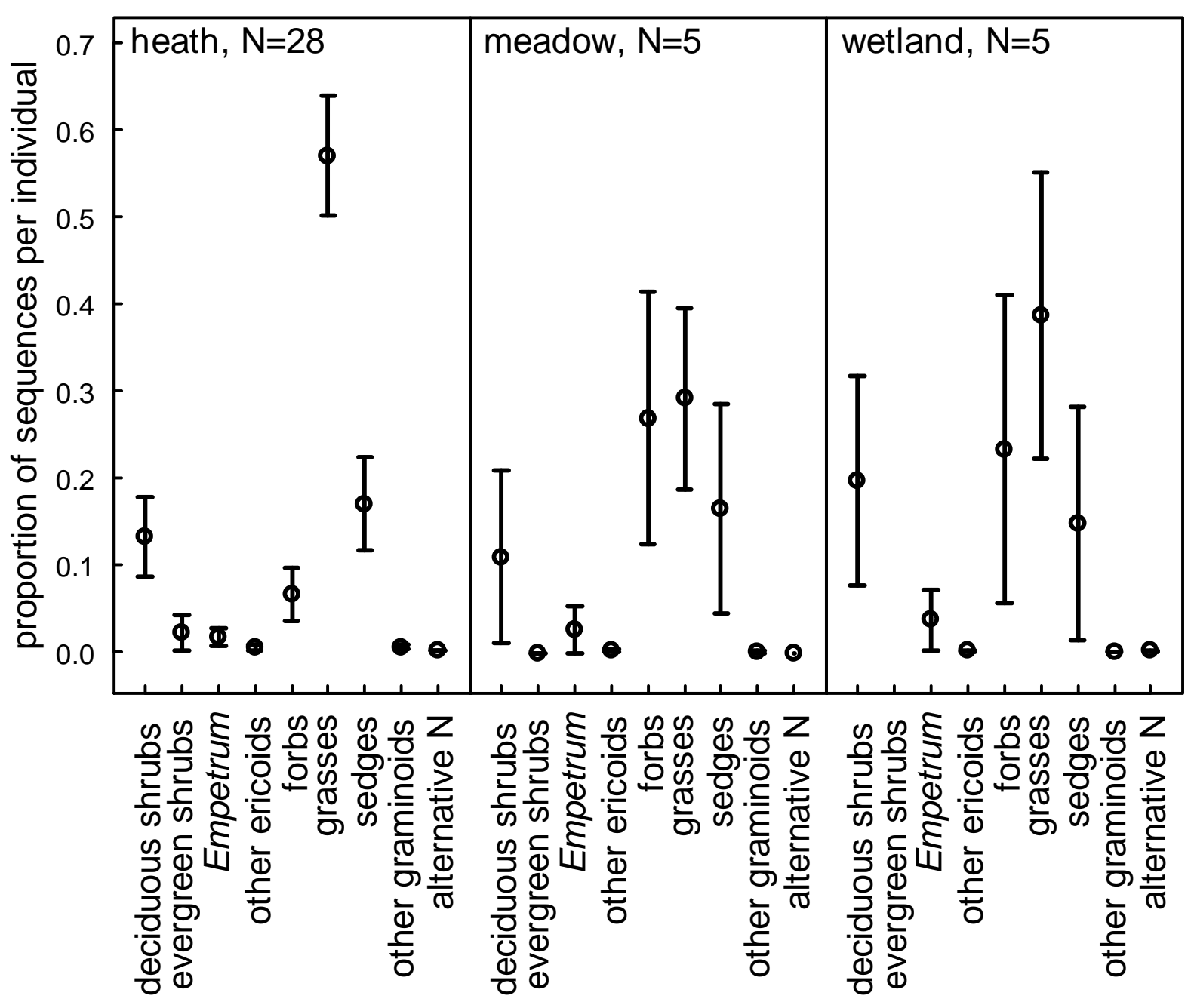

479

480

481

482

483

484

485

486

487

488

489 


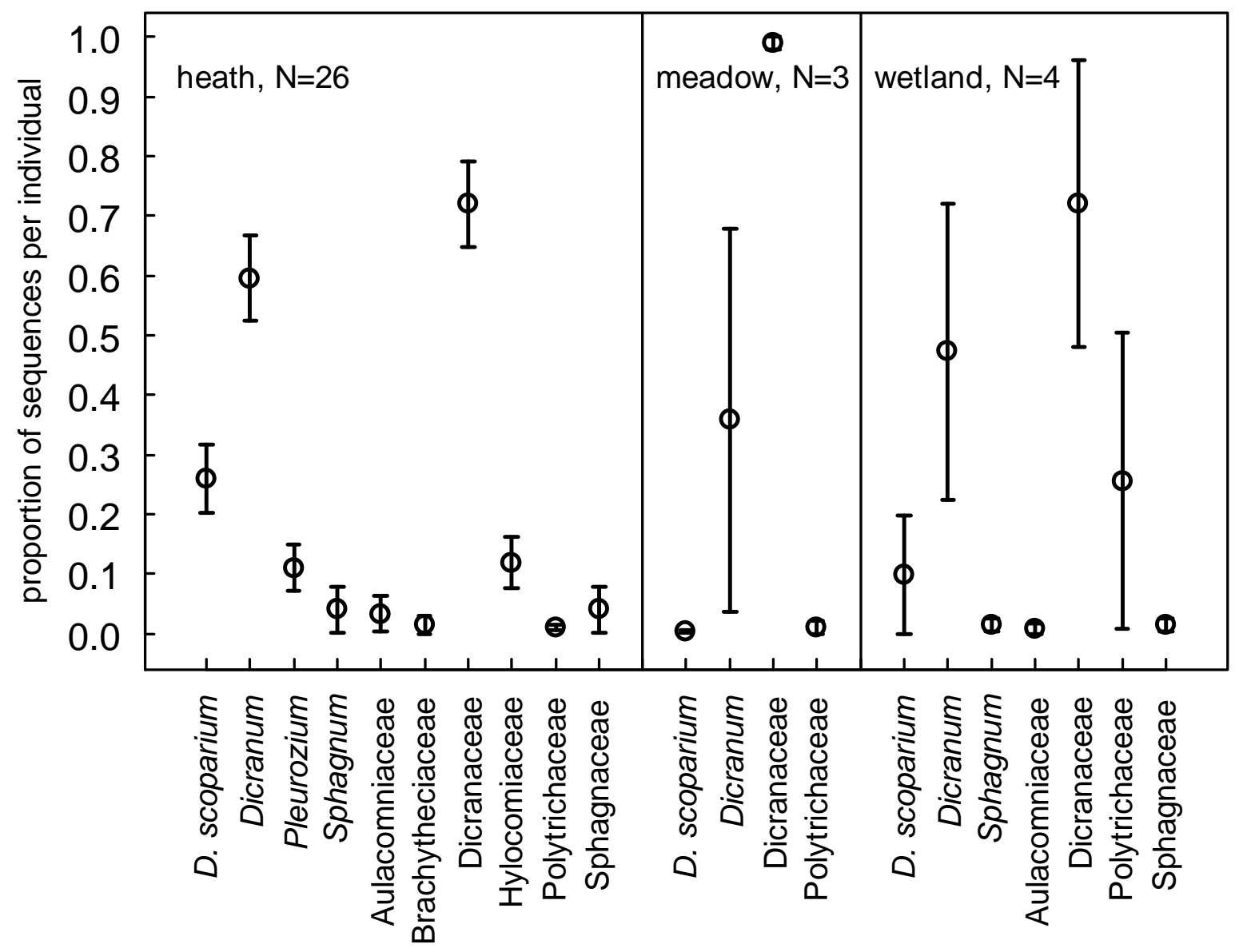

491 

metabarcoding of stomach content

\section{Appendix 1.}

\section{Details of taxonomic adjustments}

For seed plants, we first verified the taxonomic annotation of sequences based on the region's flora (Lid and Lid 2005, Mossberg and Stenberg 2005, Norwegian Biodiversity Information Centre and GBIF Norway 2012). Several vascular plant genera are represented only by one species in the study area. We therefore attributed sequences assigned to these genera to the respective species (e.g. Empetrum nigrum, Geranium sylvaticum). When a species was identified that is not present in the study area and several possible species could come in question, the adjustment was done to a less specific level (e.g. Euphrasia tatarica was assigned to genus Euphrasia). For each identified taxon, we also checked whether the taxonomic reference library included all closely related taxa possibly present in the area. If this was the case and when possible, sequences of missing taxa available in EMBL were compared to the sequences in the taxonomic reference library. If no unambiguous identification of the retrieved sequences was possible, the identification was moved to a less specific taxonomic rank (e.g. from species to genus). Furthermore, we moved sequences assigned to Vaccinium ovalifolium to Vaccinium myrtillus, because the former is not present in Europe, but the two have almost identical $g$ - $h$ region (accession numbers GQ245635GQ245641 in EMBL). In total, $99.7 \%$ and $0.3 \%$ of the sequences included in the final seed plant dataset were identified based on the combined arctic and boreal reference library and reference sequences from EMBL, respectively.

We did similar verifications for bryophytes, i.e. comparison to regional flora (Hill et al. 2006, Norwegian Biodiversity Information Centre and GBIF Norway 2012) and reference library coverage. We changed the taxonomic annotation from species to genera for two taxa. First, we moved Dicranum flexicaule to genus Dicranum, because its close relative $D$. fuscenses was not included in the taxonomic reference library and we could therefore not inarguably differentiate between these two species. Further, we moved Sphagnum russowii to genus Sphagnum, as sections are probably the lowest level of true recognition within this genus (Shaw 2000; Shaw et al. 2010).

\section{References}

Hill MO, Bell N, Bruggeman-Nannenga MA, Brugues M, Cano MJ, Enroth J, Flatberg KI, Frahm JP, Gallego MT, Garilleti R, Guerra J, Hedenas L, Holyoak DT, Hyvonen J, Ignatov MS, Lara F, Mazimpaka V, Munoz J, Söderström L (2006) An annotated checklist of the mosses of Europe and Macaronesia. Journal of Bryology 28 (198-267)

Lid J, Lid DT (2005) Norsk flora, 7th ed. (in Norwegian). Samlaget, Oslo. 
537 Mossberg B, Stenberg L (2005) Suuri Pohjolan Kasvio (in Finnish).Tammi, Helsinki.

538 Norwegian Biodiversity Information Centre and GBIF Norway (2012) Species Map Service 1.6

539 (http://artskart.artsdatabanken.no/). Accessed July 2012.

540 Shaw AJ (2000) Phylogeny of the Sphagniopsida based on chloroplast and nuclear DNA sequences.

$541 \quad$ Bryologist $103(2): 277-306$

542

Shaw AJ, Devos N, Cox CJ, Boles SB, Shaw B, Buchanan AM, Cave L, Seppelt R (2010) Peatmoss

(Sphagnum) diversification associated with Miocene Hemisphere climatic cooling? Molecular Phylogenetics and Evolution 55 (3):1139-1145. 


\begin{tabular}{|c|c|c|c|c|}
\hline Dataset & & $g-h$ & $c-h$ & ITS-Fungi \\
\hline \multirow[t]{8}{*}{ Whole dataset } & Sequences with an error in the primer & \multicolumn{3}{|c|}{2 errors allowed } \\
\hline & Sequences with an error in the tag sequence & \multicolumn{3}{|c|}{ Removed } \\
\hline & Sequences with fewer reads discarded & \multicolumn{3}{|c|}{$<4$} \\
\hline & Unrealistically short sequences removed, threshold length & 8 & 50 & 50 \\
\hline & Potential PCR errors discarded (using OBIclean ${ }^{a}$ ), criteria & \multicolumn{3}{|c|}{ clustering threshold $10 \%$} \\
\hline & GenBank database accessed & \multicolumn{3}{|c|}{$16^{\text {th }}$ April 2012} \\
\hline & Software used for sequence annotation & \multicolumn{3}{|c|}{ EcoTag (available as part of OBITools) } \\
\hline & Minimum match with reference sequence & $98 \%$ & $98 \%$ & $90 \%$ \\
\hline Final dataset of & Mean no. sequence reads per sample & 2405 (range 23-12510) & 581 (range 74-1516) & 44 (range $0-225$ ) \\
\hline \multirow[t]{4}{*}{ lemmings } & Mean no. taxa per sample in final dataset & 15.4 (range 6-27) & 8.9 (range 3-16) & 3 (range $0-9$ ) \\
\hline & Sequences assigned to species level & $45 \%$ & $57 \%$ & $12 \%$ \\
\hline & Sequences assigned to genus level & $27 \%$ & $31 \%$ & $1 \%$ \\
\hline & Sequences assigned to family level & $26 \%$ & $9 \%$ & $4 \%$ \\
\hline
\end{tabular}

Supplementary Table S1 Sequence analysis detailed for each of the three primer pairs used in order of execution. The samples were sequenced as a part of a batch of 192 samples comprised partly of samples not presented in this study. First part of the sequence analysis was done for the whole dataset of 192 samples, using software OBITools (available at http://www.grenoble.prabi.fr/trac/OBITools). Thereafter, a new dataset was composed consisting of lemmings only (focal dataset of each step denoted in the first column).

${ }^{a}=$ OBIclean (included in OBITools) identifies progressive changes of one bp, defines clusters which include a maximum threshold proportion of changed sequences, and keeps the most abundant sequence of the cluster 
552 Supplementary Table S2 Rare plant species and genera recorded in the diets of Norwegian

553 lemmings $(\mathrm{N}=40)$ during a population density peak in northern Norway using DNA

554 metabarcoding of chloroplast trnL intron. Included are taxa which composed on average <

$5550.1 \%$ of seed plants in diets, determined using primer pair $g$ - $h$ and taxa which composed on

556 average $<0.1 \%$ of mosses in diets, determined using primer pair $c-h$. See methods for

557 details. Column "Frequency" refers to the number of individuals from which the taxa in

558 question was found. Column "Change" shows taxa which identity was changed based on

559 regional flora; "+" indicates that at least part of the sequences included in the taxon were re-

560 assigned to a more specific taxonomic level,"-“ the opposite.

\begin{tabular}{|c|c|c|c|}
\hline Group & Taxa & Frequency & Change \\
\hline \multirow[t]{31}{*}{ Seed plants } & Andromeda polifolia & 1 & \\
\hline & Arabis alpina & 1 & \\
\hline & Bartsia alpina & 5 & \\
\hline & Caltha palustris & 4 & \\
\hline & Chamerion angustifolium & 1 & \\
\hline & Comarum palustre & 2 & \\
\hline & Dryas octopetala & 1 & + \\
\hline & Geranium sylvaticum & 5 & + \\
\hline & Geum rivale & 1 & + \\
\hline & Lathyrus pratensis & 1 & \\
\hline & Linnaea borealis & 1 & + \\
\hline & Lotus corniculatus & 1 & \\
\hline & Melampyrum pratense & 1 & \\
\hline & Parnassia palustris & 1 & + \\
\hline & Phalaroides arundinacea & 1 & \\
\hline & Pinus sylvestris & 4 & + \\
\hline & Saussurea alpina & 5 & \\
\hline & Trientalis europaea & 6 & + \\
\hline & Trollius europaeus & 2 & + \\
\hline & Vaccinium vitis-idaea & 4 & \\
\hline & Alchemilla & 3 & \\
\hline & Calamagrostis & 7 & \\
\hline & Epilobium & 1 & \\
\hline & Euphrasia & 1 & - \\
\hline & Galium & 2 & \\
\hline & Larix & 2 & \\
\hline & Luzula & 1 & \\
\hline & Plantago & 1 & \\
\hline & Rhinanthus & 1 & \\
\hline & Stellaria & 1 & \\
\hline & Papaver & 2 & \\
\hline \multirow[t]{2}{*}{ Bryophytes } & Hylocomiastrum pyrenaicum & 1 & \\
\hline & Hylocomium splendens & 3 & \\
\hline
\end{tabular}




\begin{tabular}{ll} 
Kiaeria glacialis & 1 \\
Lophozia wenzelii & 1 \\
Pohlia wahlenbergii & 1 \\
Saniona uncinata & 1 \\
Bryum & 2 \\
Sciuro-hypnum & 2 \\
\hline
\end{tabular}


Supplementary Table S3 Fungal taxa ingested by Norwegian lemmings $(N=40)$ during a population density peak in northern Norway, determined with the primer pair ITS5 and 5.8S_fungi on stomach content DNA. Sequences identified to lower taxonomic levels are included at the higher levels. Frequency: number of individuals in whose stomach content DNA-sequences of a taxon. Size class indicates to which fungal size class (micromycete/ macromycete) the taxa belong.

\begin{tabular}{|c|c|c|c|c|c|}
\hline Division & Class & Family & Species & Frequency & $\begin{array}{l}\text { Size } \\
\text { class }\end{array}$ \\
\hline \multirow[t]{19}{*}{ Ascomycota } & & & & 21 & \\
\hline & Dothideomycetes & & & 4 & \\
\hline & & Venturiaceae & & 3 & \\
\hline & & & Venturia sp. & 2 & micro \\
\hline & & & Venturia atriseda & 1 & micro \\
\hline & & No rank & & 1 & \\
\hline & Leotiomycetes & & & 9 & \\
\hline & & Helotiaceae & & 1 & \\
\hline & & & Gremminella sp. & 1 & micro \\
\hline & & Thelebolaceae & & 8 & \\
\hline & Eurotoimycetes & Herpotrichiellaceae & $\begin{array}{l}\text { Cladophialophora } \\
\text { minutissima }\end{array}$ & 3 & micro \\
\hline & Lecanoromycetes & Teloschistaceae & & 1 & \\
\hline & & & Caloplaca sp. & 1 & micro \\
\hline & & & Caloplaca flavocitrina & 1 & micro \\
\hline & Saccharomycetes & & & 4 & \\
\hline & & Dipodascaceae & & 4 & \\
\hline & & & Galactomyces & 1 & micro \\
\hline & & & geotrichum & & \\
\hline & & & Yarrowia lipolytica & 3 & micro \\
\hline \multirow[t]{10}{*}{ Basidiomycota } & & & & 17 & \\
\hline & Exobasidiomycetes & Exobasidiaceae & Exobasidium rostrupii & 3 & micro \\
\hline & Agaricomycetes & Schizophyllaceae & Schizophyllum sp. & 2 & macro \\
\hline & Tremellomycetes & No rank Tremellales & & 2 & \\
\hline & & & $\begin{array}{l}\text { Trichonosporales sp. } \\
\text { LM547 }\end{array}$ & 2 & micro \\
\hline & no rank & & & 14 & \\
\hline & & No rank & Leucosporidium & 1 & micro \\
\hline & & Leucosporidiales & & & \\
\hline & & No rank & & 13 & \\
\hline & & & No rank & 4 & \\
\hline No rank Fungi & & & & 38 & \\
\hline
\end{tabular}


